\title{
Impact of Climate Change on Odisha, Economic Development-A Comparative Analysis
}

\author{
Dr. Pragnya Paramita Jena
}

\section{INTRODUCTION}

Human development lunched in 1990 focuses mainly on enlargement of people's choice centering on pillars of sound education, decent standard of living and healthy life. Subsidiary choices are political freedom and various ingredients of self respect. The absence of these choices blocks many opportunities. The human development is the end while the economic growth is only a means to this end. The human development is the means for higher productivity, lowering the family size, healthy physical environment, healthy civil society, increased democracy and wider social security. The main pillars are equality, sustainability and productivity (UNDP, 2010).

Besides the economic growth, the climate has significant impact on human development (Akanbi, Satope, 2014). It is observed that development is positively correlated with the change in climate. Abnormal change and deviation from long established climate affects the soil, cropping pattern, productivity of crops, and longevity of human beings, family life and political situation. In short climate change undermines human capital, its capabilities, and freedom and otherwise the human progress. According to IPCC (2007) the developing and the least developed countries are at a higher stake of climate change than the developed countries.

As per United National Framework Convention on Climate Change (UNFCCC) is attributed directly or indirectly to human activity which has bearing on global atmosphere. Essentially the climate change is not same as weather change. Change of weather is seasonal and temporary whereas climate change involves permanency in change of weather. The established meaning of climate is the measure of the average pattern of variation in temperature, humidity, atmospheric pressure, wind precipitation and other meteorological variables in a given region over a long period of time. It is different from weather and describes the short term conditions of these variables in a given region. In narrow sense climate is average weather at least for a period of 30 years as per the World Metrological Organization.

The climate as observed is now subject to significant change. The Climate of Odisha as set up since ages and the seasons are monsoon, winter, summer, spring and autumn, occur at constant time and continues for certain period. This climate of the state has been determined due to a number of factors such as location, ocean currents, forests, direction of prevailing winds, shape of land and influenced by human to a great extend.

The above factors have changed the climate of the state to a great extent recently. Climate change has become a matter of great concern. Odisha's seasons have all but vanished, its trees have altered their flowering time, and the farmers have changed their farming practices. Not only this, of the six seasons prevalent there seems only two summer and rain that have their effects on Lands of the state. Autumn, spring and winters have slowly vanished from the memory of the people. While summers have become longer, winters have become warmer and rains have shortened from above 120 to 90 days while becoming erratic beyond point.

Climate is an important input of food grain production of the state. About 70-75 percent of state's population is rural and depends upon agriculture. The agriculture sector contributes about 16 percent of GSDP during the year 2011-12, which has come down from a level of 53 percent in 1980-81, with almost 60 percent of land under rain fed agriculture and with water-dependent rice, as its main crop, the agriculture sector is particularly vulnerable to vagaries of climate change. The normal rainfall of the state is $1451.2 \mathrm{~mm}$ out of which 75-80 percent is received from June to September by the impact of south west monsoons. But data shows that the rainfall has decreased to $1391.3 \mathrm{~mm}$ in the year 2012, and it was $1007.8 \mathrm{~mm}$ in the year 2002. The year 2015 is particularly significant for long spell of drought and monsoon failure. This has affected farmers of the state.

The climate shocks are the crucial factors that have pushed back the progress of the economy. According to a study Status of Agriculture in Odisha, Directorate of Agriculture, Odisha, out of 52 years only thirteen years have been normal years and in all other years the state has been bearing the impact of climate shocks. This almost puts the state with a 75 percent probability of being visited by these climate shocks of any kind. Further it is also observed that there is consistent loss of rice productions because of these events. The climate change has the potential to derail the current growth strategy and deepen poverty in Odisha. Continuing climate variation has altered the sectoral growth including the ability of the poor to engage in farm and nonfarm 
activities. In short the climate as an important input holds the key for enhancement of food grain productions and assurance of food security of the people of the state.

Because of which Odisha remains the poorest of the 11 major Indian states, with 47.15 percent of the rural population (or 17.35 million people) living below the poverty line. Incidence of poverty in Odisha is 32.59 percent as against India is 21.92 percent in the year 2011-12 according to Odisha Economic Survey, 2014-15.

However impact of climate change is just not confined to agriculture, it is impacting other areas of development too. Risk and vulnerability is getting compounded due to devastating natural, social, physical, economical and environmental capital, combined with poor political representation followed by nutritional and health hazards causing to disrupting the livelihoods that causes distress migration. Migration of families triggered by crop failure has affected education and health of people. Children often accompany their parent in their search of livelihood in cities beyond the state. They fall into the trap laid by human trafficker, child prostitution rackets, child sale, women trafficking with rampant social, mental and physical abuse and are exposed to inhuman work environment often facing exploitation and subject to inhuman drudgery.

A study conducted by the National Commission for Rural Labour (1996) stated that the number of decadal inter-state migration is about 11 million, when compared the state wise out migration for economic reasons was very high for Bihar (48.7\%) followed by Orissa (41.6\%). With unproductive landholdings and very few means of sustenance, the rural poor are plunged into crisis every year. Their only option is to migrate to other states in search of work. Seasonal migration, distress migrations are mostly found in this particular state, where people suffer from poverty, inequality and underutilization of resources. Young men leave the state's coastal districts like Ganjam to work in textile mills, shipyards and the diamond-polishing shops of Gujarat and Mumbai. People in western Odisha, especially the districts of Kalahandi, Koraput and Bolangir, travel to neighbouring Chhattisgarh to work in its farms, or migrate to the brick kilns in the South (sometimes to the ones in the North as well).

Action Aid estimates that nearly 200,000 people migrate from Western Orissa to brick kilns surrounding major cities of Andhra Pradesh (Action Aid, 2005). Research conducted under the DFID-funded Western Orissa Rural Livelihoods Project (WORLP) in Nuapada and Bolangir shows a dominance of STs and SCs in migration streams from these poor districts. Literacy and education are both indicators and instruments of socio-economic development. Knowledge base, levels of skills of the people and evolution of art and culture in a society depend on education. The literacy in Odisha is 72.9 percent as par with national average 73 percent according to 2011 census where the male literacy rate is 81.6 percent and female literacy rate is 64.0 percent but there are substantial social, regional and gender disparities in literacy.

Health is a critical component of human development. Improved health is desirable not only in itself, but also because it leads to enhanced capacity to work and participate in economic activities. Climate change affects human health directly. (eg impacts of thermal stress, death/injury in floods and storms) and indirectly through changes in the ranges of disease vectors (e.g, mosquitoes), water borne pathogens, water quality, air quality, and food availability and quality.

The mortality rate is a robust indicator of the overall health status of a population. The Crude Death Rate (CDR) in Odisha in the year 2013 is 8.4. According to human development report, 2000, infectious and parasitic diseases account for a little more than one-fifth of all deaths in Orissa. Diseases of the circulatory system also have a share of nearly one-fifth in all deaths. Pre natal deaths account for 13 per cent of all deaths. Diseases of nervous system, respiratory system and digestive system together account for another, 20 percent of all deaths, in Odisha. A study conducted by on Adaptation Strategy for reducing Mortality from heat waves, evidence from a Disaster Risk Management Program in India, Odisha reveal that increase in number of heat waves days is associated with increased causalities in Osiaha which may be due to adaptive failure or physiological reasons (smith et.al 2012). The heat wave of summer in 1998 has taken 2042 human lives, the super cyclone of 1999 has also taken thousands of lives, is still a nightmare to the people living in Odisha. Frequent flood, drought and cyclones like Phalin (2013) and Hud Hud (2014) have caused massive destruction in Odisha in the past few years crushing the economic strength of families in Odisha.

Low human development index is further propelling more vulnerability thus bringing in long term destitution for people who could have otherwise led a life of dignity. At this juncture it is important to bring to light both traditional and technology supported coping mechanism so that the effect of climate change does not continue to have paralyzing effect on rural economy. So the study needed to explore critical link between the impact of climate variations and scopes for human development in the state of Odisha.

\section{REVIEW OF LITERATURE}

UNDP (2008) in his study tried to find out that the impact of Indian agriculture, still mostly rain fed are mostly disastrous. Increasingly pests' attacks accentuate the crises being felt by millions of marginal and small farmers. Human health is affected by an increase in vector- borne disease like malaria. The coastal areas of the country are threatened by a rise in sea level leading to crises of drinking water caused by saline ingress and 
infrastructure and flow loss. Climate change increases the vulnerability of the poor and those dependent on natural resources for their livelihood. It leads to less secure livelihood, increasing health risk and constrained economic opportunities due to short term and long term impacts on drought and floods. Khosla, Hunter (2007) in their study has stated that in the face of climate related environmental change rural resident are forced to migrate in search of work, creating new migration patterns. Brown (2008) has found out that according to United Nation Population Fund's State of the world population 2009 there will be an increase in migration trends which would reach up to 200 million by 2050. Brooks (2003) made an attempt to develop a conceptual framework of risk, vulnerability and adaptive capacity that synthesizes a variety of approaches. By distinguishing between social and biophysical vulnerability the apparent conflict between different formulations of vulnerability in the climate change literature can be resolved.

Chandran (2013) has tried to found out that Climate change is a human development issue which undermines expanding human potential, developing capabilities and enlarging freedom. Climate change poses major obstacles to progress in meeting the Millennium Development Goals (MDGs) and maintaining progress raising the Human Development Index (HDI). Climate change is closely linked to the broader sustainable development agenda to reduce poverty, child mortality and morbidity.

\section{Objective of the study:}

The climate change is associated with the vulnerabilities of human system arising from climate variability. The study envisages analyzing the impact of climate change on human development. The study envisage specifically:

1. To find out the change in land use pattern, cropping system and productivity of the major crops.

2. To study the change in rate of migration, skill, pattern of employment and other related factors in the area under study.

3. To make an analysis of the standard of living, literacy and human health status.

4. To make a comparative analysis of development in both the districts.

\section{Conceptual Framework:}

The World Bank has divided Odisha into four regions. And climate varies from regions to regions. Odisha is highly vulnerable to the levels of impact of climate change. Climate is affecting economic development and associated with poverty. The climate is shaping standard of living, employment, education, health etc. The economic development of different regions is highly associated with change of climate. In the coastal areas of Odisha, there erratic and untimely rainfall increased the salinity of the soil due to frequent tidal surges, rising temperature, increasing frequency and intensity of cyclones and low pressure during crop seasons has hit the main crop paddy. These factors have also led to increase in pests attacks. Expenses on production have increased on account of investment in increasing quantities of costly chemical fertilizers and pesticides. Facing crop losses as well as fall in income level the small and marginal farmer has abandoned agriculture.

Frequent drought is also punishing the people to a more vulnerable condition. Farmers borrow money at high interest rate and invest in agriculture production but sudden drought, drag the farmers towards poverty and hinder their development. So climate is affecting economic development.

\section{Hypothesis:}

Due to climate change there is a change in land use pattern, cropping system and productivity of major crops like rice, cereals and pulses.

There is a change in rate of migration, productivity of human beings and pattern of employment.

There is a change in standard of living, literacy and human health.

\section{Area of the Study:}

\section{METHODOLOGY}

The study will be confined to the districts of Puri and Balangir of the State to study the impact of climate change on human development. Districts has been selected purposively, Puri representing the coastal zone associated with more rain, cyclone and flood as against Balangir represents western Odisha associated with high temperature, more migration, low and erratic rainfall.

\section{Sampling Technique and Study Design:}

Multi-Stage sampling technique will be adopted to select the sample units. In the first stage, Puri and Balangir districts will be selected purposively, Puri representing coastal and Balangir western Odisha. In the second stage two blocks from each district will be selected purposively. In the third stage from each selected blocks two Gram Panchayats total eight Gram Panchayats will be selected purposively on the basis of above parameter. From each Gram Panchayat one cluster of four to five villages will be selected. From each cluster of 
village's 75 farmers consisting of large, small and marginal will be selected. Number of farmers will be selected on the basis of proportion to the number of farmer existing in the group of farmers. The sample will be interviewed about economic condition, size of land, productivity, education and other socio economic factors. The farmer will be interviewed with structured questionnaire on personal contact.

\section{Sample selections:}

The sample size contains four blocks, eight gram panchayats, fourty villages and six hundred respondents.

\section{Sources \& Tools of Data Collection:}

The data for the study were collected from both primary and secondary sources. The data collection from the primary sources will include interview with respondents through a semi-structured pre-tested questionnaire and researcher's observation. The questionnaire covered personal, demographic, social and economic information, details of participation, perception on cohesion and impact and constraints of climate change. Besides, focused group discussion, informal interview method, participant observation method will also be used to collect information relating to the study. The various sources for collecting secondary data will include human development reports, UNDP reports, ADB reports, published and unpublished documents including journals, books, occasional publications, working papers, popular magazine and annual publications of social development organizations and others.

Proper Statistical analysis will be used to analyse the data in view of the stated objectives. The data after collection will be edited then there will be gap filling and if necessary again visiting the field for collection of data will be done. The data will be analysed with the help of statistical tables and diagrams. Trend and regression analysis will be done in view of the objectives.

\section{REFERENCES}

[1]. Akanbi, Bosede E. Adagunodo, Mathew, Satope, Bola F, "Climate Change, Human Development and Economic Growth in Nigeria" International Journal of Humanities and Social Science, Vol. 4, No. 13; November 2014. Available at http://www.ijhssnet.com/journals/Vol_4_No_13_November_2014/26.pdf

[2]. Brooks; N (2003) Vulnerability, risk and adaptation: A conceptual framework, Tyndall Centre for Climate Change Research, working paper: No. 38.

[3]. Brown, O (2008), Migration and climate change. Geneva. International Organisation for Migration.

[4]. Chandran. KPV.,Sandhaya. PClimate Change and Human Development: A Pragmatic Approach. Available https://www.researchgate.net/publication/236604893_Climate_Change_and_Human_Development_A_Pr agmatic_Approach

[5]. Economic Survey, Odisha: (2009-2010), Planning and coordination department, Directorate of economics and statistics, Government of Odisha.

[6]. Economic Survey, Odisha, 2014-2015. Government of Odisha

[7]. Human Development Research Paper, 2010/01 Human Development: Deᄀnitions, Critiques, and Related Concepts. Available at

[8]. http://hdr.undp.org/sites/default/files/hdrp_2010_01.pdf

[9]. IPCC, 2001a . Climate change (2001), Synthesis report . A contribution of working groups I, II, III to the third assessment report of the intergovernmental panel on climate change, R.T.Watson and the Core Team, Eds., Cambridge University Press, Cambridge and New York, 398 pp.

[10]. IPCC 2007: Fourth Assessment Report on Global Status of Climate.

[11]. Khosla. R, The New Economic and climate Context and changing migration pattern in India. Centre from Urban and regional Excellence (CURE), Unpublished.

[12]. Linking Climate Change Policies To Human Development Analysis and Advocacy. Available at http://hdr.undp.org/sites/default/files/nhdr_climate_change_gn.pdf

[13]. Mukherjee1S, Chakraborty D, Sikdar S, 2014," Three Decades of Human Development across Indian States: Inclusive Growth or Perpetual Disparity?". Available at http://www.nipfp.org.in/media/medialibrary/2014/06/WP_2014_139.pdf

[14]. Mitra, A (2008) Climate Change Adaption Activities in India, supported by UNDP. Published by Gorakhpur environmental Action Group.

[15]. Nath , P. K and Chauhan, H (2016) Mainstream, VOL LIV No 16 New Delhi April 9, 2016 ,Political Economy of Farmers' Suicide A Case of Western Odisha Available at :http://www.mainstreamweekly.net/article6328.html

[16]. Odisha Agriculture Statistics (2008-09), Directorate of agriculture and food production, Odisha, Bhubaneswar. 
[17]. Shah A., Nayak S. K., Das B., (2005), Remoteness and Chronic Poverty in a Forest Region in Southern Orissa: A tale of entitlement failure and state's apathy. CPRCIIPA seminar on 'chronic poverty: Emerging policy options and issues', Indian institute of public administration, New Delhi, pp 29-30.

[18]. Smith, Stephen C, Das Soudamini (2012) Awareness is an Adaptation strategy for reducing Mortality from heat waves: Evidence from a Disaster Risk Management Program in India. Institute for International Economics Policy, New York, working Paper, 2012-6

[19]. United Nations Framework Convention on Climate Change, Fact sheet: Climate change science - the status of climate change science today, 2011. Available at https://unfccc.int/files/press/backgrounders/application/pdf/press_factsh_science.pdf 